\title{
THE REPRESENTATION OF STATUS IN MANDE: DID THE MALI EMPIRE STILL EXIST IN THE NINETEENTH CENTURY? ${ }^{1}$
}

\author{
Jan Jansen \\ Research School CNWS \\ University of Leiden
}

I

For the reconstruction of the history of the aftermath of the Mali empire, that is, the period 1500-1800, oral traditions are the only source of information. The history of this period has been reconstructed by Person and Niane. ${ }^{2}$ Their work has gained widespread acceptance. ${ }^{3}$ In this paper I will argue that these scholars made significant methodological errors--in particular, in interpreting chronology in genealogies, and their reading of stories about invasions and the seizure of power by younger brothers. ${ }^{4}$

My reading of the oral tradition raises questions about the nature of both sixteenth- and nineteenth-century Mande (that is the triangle Bamako-KitaKankan (see map), the region where the 'Malinke' live), and the medieval Mali empire, because I think that Mande royal genealogies have wrongly been considered to represent claims to the imperial throne of the Mali empire. In contrast, my reading of oral tradition suggests in retrospect that the organizational structure of the Mali empire may have been segmentary, and not centralized, ranking between segments under discussion, each group thereby creating a hierarchical image.

The conventional wisdom seems to be that the Mali empire collapsed/disintegrated in the period from 1500 and 1800. As Person put it:

Dans le triangle malinké, on ne trouvera plus au XIX siècle que des $k a f u$, ces petites unités étatiques qui forment les cellules politiques fondamentales du monde mandingue. Certains d'entre eux savaient faire reconnaître leur hégémonie à leurs voisins, mais aucune structure politique permante n'existait à un niveau supérieur. Beaucoup d'entre eux, dont les plus puissants et les plus peuplés, seront alors commandées par des lignées Kééta qui se réclament avec quelque vraisemblance des empereurs du Mali médiéval. ${ }^{5}$

In order to reconstruct the history of the presumed aftermath of the Mali empire, Person made some choices in his material. He put the Sunjata epic aside, because "celle-ci constitue une section isolée," and "sa fonction est

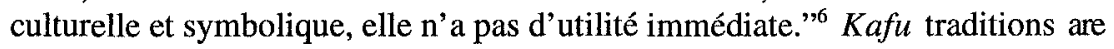
also of no use, since these, "au contraire, ont pour fonction de justifier l'ordre politique existant au XIXe siècle." ${ }^{.7}$ Therefore Person used only material which is more recent than the Sunjata epic, which he considers to refer to the

History in Africa 23 (1996), 87-109. 
thirteenth century. He admitted that this material is rather rare and not so fixed as the genealogies in the Sunjata epic, and that this poses serious problems, but otherwise he presented ambitious genealogical schemes designed to convince the reader that the disintegration of the Mali empire began at the end of the sixteenth century, after the reign of a semi-historical king whom he called "Nyaani Mansa Mamadu."

My main argument is that Person erred in isolating the traditions "more recent than Sunjata." I will argue that all traditions-that is, the Sunjata epic, more recent traditions, $k a f u$ traditions, and origin stories-are characterized by the same patterns. These characteristics make them on the one hand almost useless for the reconstruction of the past, but on the other hand show that nineteenth-century Mande society was much more unified than Person thought, although it had a segmentary character. I hope to show that western attitudes towards chronology are not valid in the analysis of Mande tradition, because the group with military power represents itself as a younger brother (within a genealogy) or a recent invader (in a foundation story).

The principal focus of this paper is the position of Kangaba. This famous town in Mande, a center of power in the nineteenth and twentieth centuries, has been considered the seat of a Keita branch which seized power some centuries after the collapse of the Mali empire. ${ }^{9}$ I will argue that this opinion on Kangaba is merely the product of methodological mistakes. My emphasis on Kangaba springs from the fact that I carried out ten months' fieldwork in the region of Kangaba between 1991 and $1994 .{ }^{10}$ The present paper, however, is based on published sources. All the genealogies mentioned in this article may be considered as widely accepted in the region of their origin.

Living in the village of Kela, as the guest of its famous griots, I recorded dozens of praise songs (fasaw) for Sunjata. In these praise songs the bards always proclaimed a list of names, a so-called genealogy, in which they placed their own patrons, the rulers of Kangaba, called the Keita Kanda-si (=the branch of Kanda), in the role of descendants of the youngest great-grandson of Sunjata. ${ }^{11}$ The list typically runs as follows:

He descends from six sorcerers:

Joma Nyama,

Joma Jinama,

Finadugu Koma,

and Kanku Bori,

and Mansa Kuru, and Mansa Kanda. 
In the beginning of my research I hardly took this genealogy seriously, since I considered the position of the youngest brother as not very prestigious in a society in which age is the main criterion governing succession. However, I had to wonder why the bards and their audience seemed to enjoy hearing the confirmation of this youngest brother's position again and again.

Mande was one of the last parts of the Sudan to be occupied by European imperialist powers. ${ }^{12}$ Although the region was thought to have been the location of a once great empire, the first expedition to Mande took place only in 1879. Lt. Vallière, commander of this expedition, knew about the gold mines in Mande and the former Mali empire, as well as that its present-day "malinké" population was aggressive and hard to handle. ${ }^{13}$

Vallière met a population which seemed divided by rivalry between 'brothers,' petty rulers who made war with each other. He sounded rather disappointed when he concluded the account of his expedition:

La nation manding manque absolument d'unité, et il faudrait, sans doute, remonter bien loin dans son histoire pour la trouver consituée avec un gouvernement reconnu par tout le pays. Chaque village vit séparément avec son chef particulier et, bien que ces chefs appartiennent tous aux deux ou trois familles les plus illustres, ils n'ont, malgré ces liens de parenté, aucune solidarité d'intérêts. ${ }^{14}$

Vallière complained that the people had not learned anything of the recent attacks by the armies of El Haji Omar. He continued:

Les villages les plus voisins se jalousent et se détestent à l'egal de l'étranger. Si une alliance existe entre deux localités, elle est de courte durée, car ik surgit toujours quelque différend qui, à défaut de tribunal suprême, se regle, comme nous l'avons dit déjà, à coups de fusil. Chose étrange! ces divisions profondes et l'isolement de chacun n'ont pas détruit l'ancien orgueil national....Singulier patriotisme qui consiste à exalter le pays et à exécrer ses compatriotes.

Vallière's superior, Gallieni, had the same opinion, and concluded: "En somme, le grand empire malinké, dont l'existence a été signalée par M. le général Faidherbe, n'existe plus arjourd'hui." ${ }^{\prime 5}$ In a later work Gallieni retained his first impression: "Les villages du Manding vivent chacun avec leur autonomie; ils n'ont entre eux que des liens de parenté et de communauté. Il n'existe à proprement parler ni confédération, ni canton, mais des alliances verbales selon les circonstances et les individus." 16

Such opinions were later confirmed by historians. For instance, Leynaud and Cissé quoted Gallieni's words in order to illustrate nineteenth-century Mande society, and Person agreed. ${ }^{17}$ 
Although Mande society was considered to be rather chaotic, in precolonial times the town of Kangaba had a high prestige everywhere in the Sudan. For instance, Mungo Park mentioned the town as an important slave market. ${ }^{18}$ A century later the ruler of Kangaba, who collaborated with the armies of Samory Toure, was one of the main opponents of the French. This ruler lived in a two-story palace that has been described as an architectural masterpiece. ${ }^{19}$

In spite of the fame of the town of Kangaba, its ruler was considered to be an usurper who dominated other, legitimate, rulers, and the French sent him and his family into exile. ${ }^{20}$ They did so because both the ruler of Nyagassola and the ruler of Figira were the 'older brothers' of the ruler of Kangaba. Since succession is collateral and along rules of seniority, the rulers of Kangaba were thereby deemed to have no legitimate claim to rulership over group whatsoever. Moreover, all the regional traditions were unanimous about the recent origin of the rulers of Kangaba. Among all the rulers in the region, the rulers of Kangaba were said to have arrived the most recently.

\section{The genealogy of the rulers of Kangaba}

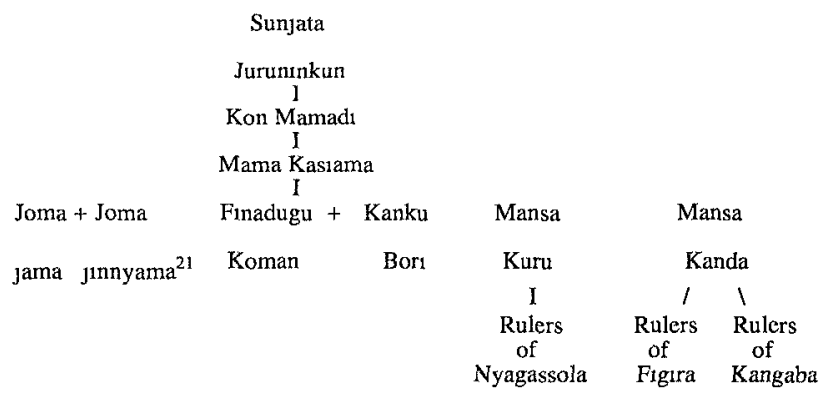

This genealogy is a geographical blueprint of the region around Kangaba. The names of the six brothers clearly represent kafuw in Mande. The Joma region is south of Kangaba, around the town of Siguiri, and this is the region where the descendants of the two oldest brothers ruled. ${ }^{22}$ Finadugu is a kafu north of Kangaba. The Keita of Kenyoroba and the Keita of Narena are groups of Keita rulers who claim descent from him. ${ }^{23}$

The descendants of the two youngest brothers are well represented in number. Rulers of powerful towns such as Nyagassola and Narena claim descent from Mansa Kuru. His name clearly represents a landscape characteristic, since "Mansa" means "king" and "Kuru" means "hill" or "mountain," and Narena and Nyagassola are in the Mande hills. The descendants of Mansa Kuru are Kangaba's direct opponents, and thus one sees that the 'older brothers' live at a rather short distance of Kangaba. When 


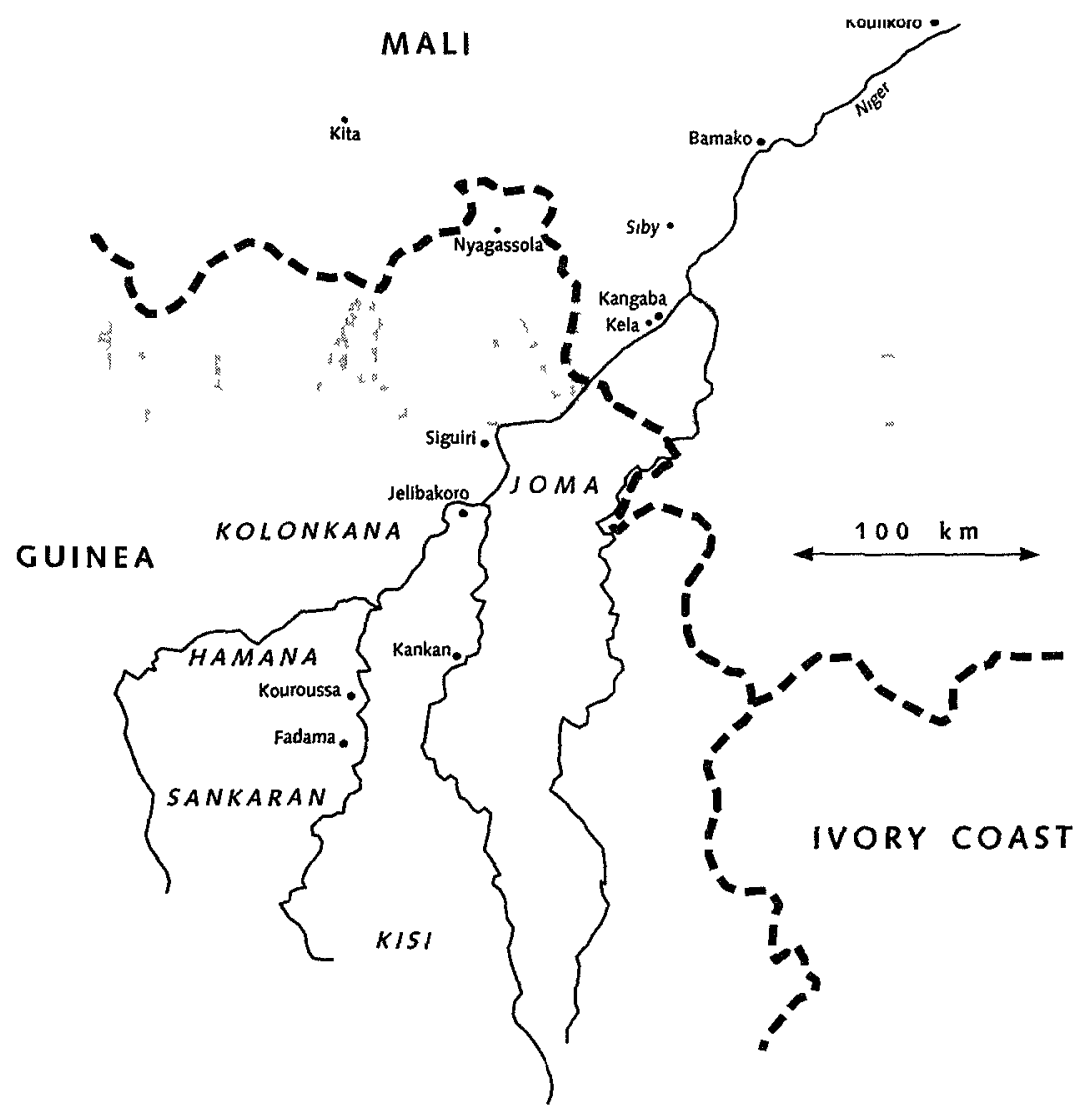


Vallière left Kita in order to explore Mande, he had to cross the Mande hills. Nyagassola was the first Mande town he encountered, and the French built a fortress there to protect the town from plunder. This pro-Nyagassola policy was partially due to the good contacts between the French and the ruler of Nyagassola. In particular, the French captain Peroz was impressed by the people of Nyagassola, writing that its ruler Mambi addressed him as "ma mère." 24

The youngest brother is Kanda. According to some people, this word is said to have the meaning of "war chief." ${ }^{25} \mathrm{~A}$ few Keita rulers-for instance, those from Figira and Kangaba-trace descent from Mansa Kanda. Figira is a small town on the right bank of the Niger, a region which still is rather isolated from the rest of the world.

Although its rulers were said to be usurpers, adjoining towns still had a lot of respect for the rulers in Kangaba. For instance, Mambi told Vallière that his "younger brother" in Kangaba, another Mambi Keita, was a very brutal man; Nyagassola and Kangaba had been in war for generations. However, when Vallière left Nyagassola, the same Mambi advised him to visit Kangaba, where he would be received there with the same hospitality he had enjoyed in Nyagassola. Since he wanted to visit Gallieni, however, and since the rains slowed the progress of his exploration, Vallière decided instead to go directly to Bamako. ${ }^{26}$

Mambi of Nyagassola's advice was not a coincidence. He clearly acknowledged the importance of Kangaba, since Mambi of Kangaba had married two princely women from Nyagassola. ${ }^{27}$ This shows the existence of a diplomatic relationship between the two towns, although-as the French duly noted-the rivalry between Kangaba and Nyagassola was so vehement that the towns always chose contrary positions. ${ }^{28}$

The French chose the side of Nyagassola and this determined automatically the fate of Kangaba, which chose a stand against Nyagassolaand the French. French colonial policy was systematically directed against Kangaba and its area of influence (maara) was split into several administrative units, while the position of yamanatigi (chief of the canton) of Kangaba was given to the 'older brother' from Figira.

The rulers of Kangaba were sent in exile until 1909. These measures were not only a reward for the support the French had received from Figira and Nyagassola; they were thought to be justified by the rules of collateral succession, which determined that older brothers come first. Nonetheless, the people of Kangaba always resisted the ruling family from Figira, although they had to wait until 1951 for the former ruling family to be restored. ${ }^{29}$

Thus we have some interesting historical phenonema: villages in constant rivalry, rapidly changing alliances, incomprehensible feelings of unity, usurpation by a younger brother and-rather surprisingly-non-acceptance of the older brother, the alleged legitimate successor. In order to explain the logic of this situation, it is necessary to work out the patterns along which leadership and status were expressed in Mande society. Genealogies of Mande rulers show these patterns more explicitly. 


\section{III}

Mande genealogies are strongly influenced by principles of settlement and segmentation in Mande society. This aspect has been overlooked by many scholars, since Mande genealogies look similar to such things as the lists of successive rulers in European states. However, Mande genealogies appear to be primarily ideological constructions based on the principle of settlement. The genealogies presented here are still acknowledged in the areas where their members' descendants ruled in the nineteenth century. None of these genealogies refers to a recent past, but to the times of the foundation of Mande society and its immediate aftermath. Every genealogy - that is, those of Sunjata, as well the kafu traditions-has been structured along principles of patrilocal settlement and patrilineal descent, two characteristics of Mande society.

In the ideal situation brothers remain in the paternal compound and belong to one patrilineal group (bonda). Male members of a bonda consider each other as 'brothers,' distinguishing only on the basis of age. In daily life, any male inhabitant is surrounded by dozens of classificatory fathers, older brothers, younger brothers, and sons. Since bondaw are located next to each other, in the long term a person older in age can be the classificatory son of a younger person.

Thus, if there should be no tension, compounds would grow larger and larger, populated by numerous (classificatory) fathers, brothers, and sons. Therefore segmentation is necessary. Segmentation takes place along two lines in Mande, whatever its direct cause (for instance, famine or struggle for succession). Compounds sometimes split up when the genealogical distance between classicatory brothers has grown too large. Segmentation can also take place between half-siblings. Since Mande society has a polygamous marriage system, tension may arise between half-brothers or groups which claim descent from half-brothers. ${ }^{30}$

Figure 1 does not include women, giving only a difference in age and a genealogical distance. The difference in age is confirmed by the terminology used by the rulers of Figira and Nyagassola, who both claimed to be the older brother of the ruler of Kangaba.

The position of the rulers of Kangaba--the youngest brother according to their own genealogy - must be seen in a different light when other genealogies are taken into account. I will illustrate how rulers tend to represent themselves in the position of the youngest brother and place their neighbors-their rivals - in the position of older brothers. This mechanism can be found on a supraregional level in the genealogies of Sunjata's family, and on a regional level in the genealogies of the descendants of Sunjata (for instance, in figure 1).

Take the genealogy of the ruiers of Kita, a town located about 100 miles from Kangaba, and separated by the Mande hills. In the Kita tradition Sunjata is said to have had eight sons. 'The oldest, Nyamagan, settled in Kita, followed by his younger full brother Jinè Magan. The names of the other six sons are 
not mentioned. Nyamagan is said to have left for Siguiri, leaving Jinè Magan in Kita. The praise song for the town of Kita contains their names: ${ }^{31}$

Je vous parle de Kita...De Kita Kuru et de Mansa Ganda De Nyamagan et de Jine Magan

Kita praise songs contain names that are also found in the royal genealogy of Kangaba. In both genealogies the duo Nyamagan/Jomamagan and Jinè Magan/Jinnenyama are said to be the oldest. However, when recited as a praising, Kita Kuru/Mansa Kuru and Mansa Ganda/Mansa Kanda come first, thus suggesting that they are held the oldest. ${ }^{32}$ The departure of the oldest brother is remarkable, since this means that the Keita of Kita themselves claim to descend from a younger brother. Here is a similarity with the other center of power, Kangaba, whose rulers also claim to descend from a younger brother.

The logic of the situation becomes clear when data from Siguiri, the main town of Joma, are taken into account. Niane writes that a "branche cadette" moved from Kita to Joma. ${ }^{33}$ Thus the Joma perspective is the reverse of the Kita perspective, except that both claim descent from a younger brother. Person's research more or less confirms this principle, since he claimed that, according to people from Hamana (southwest of Joma), the Keita of Kita are a younger branch of the Keita of Joma. ${ }^{34}$

Joma's position as the oldest brother in figure 1 is not unique for the Kangaba region. This position has been attributed to the Joma rulers in many other genealogies from Mande, leading Person to believe that the Joma rulers were the legitimate heirs of the imperial title. ${ }^{35}$ However, this older brother position of the Joma rulers has been accepted everywhere, except in the Joma region by the Joma rulers themselves.

The same reversal of positions is found in the genealogies presented by Person, but he neglected this problem. ${ }^{36}$ In his final analysis, Person presents Mansa Kanda as the youngest son of Niani Mansa Mamadu, but "le seul qui fasse exception à cette regle est celui de Hamana, bien connu par sa capitale Kouroussa." ${ }^{37}$ In Kouroussa, however, Mansa Kanda is considered to be the older brother. For Person this exception proved the source to be useless. Later I will argue that this exception is crucial for our understanding of Mande genealogies. It is actually to be expected that the rulers of a powerful town as Kouroussa represent themselves in a contrary position.

So far, the genealogies of the descendants of Sunjata are similar to the principles of settlement in terms of brother-brother relations, and this means that they represent tension and mutual acknowledgment, when genealogical distance is great. Moreover, relations between brothers are in terms of seniority. Genealogies never mention women, and this means that the rivalry between half-brothers is absent. Within a wide region the genealogies are transformations of the same set of names. Centers of power (e.g., Kita, Kangaba, Siguiri, Kouroussa) present themselves in the position of the younger brother, and at the same time place their rival dynasties in the position of the older brother. 
I have focused on the descendants of Sunjata, but now turn to the dynasties who are related to him one level higher. Not all the princely Keita are descendants of Sunjata. South of Joma, in Hamana and Kolonkana, live princely Keita who descend from Sunjata's younger brother Mande Bori. Even further south, in the forests of Kisi, live princely Keita who descend from Sunjata's older brother Mansa Dankaran Tuman.

The following three genealogies suggest that Person improperly neglected them, and therefore improperly neglected the Sunjata epic, in his analysis, because they show an interesting variety. Moreover, they show the same preference for the position of the younger brother as has been found in the genealogies of the descendants of Sunjata. The following genealogy has been recorded often in the region of Kangaba. ${ }^{38}$

\section{The royal family: the Kangaba/Kela perspective}

\begin{tabular}{|c|c|c|c|}
\hline Farako Makan & Tasuma Berete & Sogolo & Kejugu \\
\hline Kunkenyı & (ftrst wife) & (secons & wife) \\
\hline & I & I & I \\
\hline & Mansa Dankaran & Sunjata & Mande Borı \\
\hline & Tuman & & \\
\hline & I & I & I \\
\hline & I & I & I \\
\hline & Keita-rulers & Keita-rulers & Kerta-rulers \\
\hline & from Kisi & from Kangal & from Haman \\
\hline
\end{tabular}

In Hamana and Kolonkana, the region in which the town of Kouroussa dominates, the same order is accepted, although with a slight difference: this genealogy contains a half-sibling construction.

\section{The royal family: the Hamana perspective ${ }^{39}$}

\begin{tabular}{|c|c|c|c|}
\hline Farako Makan & Tasuma Berete & Sogolon Kejugu & Namandje \\
\hline \multirow[t]{4}{*}{ Kunkeny1 } & (first wife) & (second wife) & $\begin{array}{l}\text { Camara } \\
\text { (third wife) }\end{array}$ \\
\hline & $\stackrel{\text { I }}{\text { Mansa Dankaran }}$ & $\stackrel{\text { I }}{\text { Sunjata }}$ & $\begin{array}{c}\text { I } \\
\text { Mande Borı }\end{array}$ \\
\hline & $\begin{array}{c}\text { Tuman } \\
\text { I } \\
\text { I } \\
\text { Keita-rulers }\end{array}$ & $\stackrel{\text { I }}{\text { I }}$ & $\frac{\text { I }}{\text { I }}$ \\
\hline & from Kisı & from Kargaba & from Hamana \\
\hline
\end{tabular}

The introduction of a third wife eliminates the sibling relation between Sunjata and Mande Bori in the Kangaba perspective. Thus, if one takes into 
account the principles of segmentation in Mande society, one can argue that the descendants of Mande Bori see a kind of rivalry between the descendants of Sunjata and themselves, while the descendants of Sunjata do not.

It is interesting to look at the story which tells of the relationship between the two brothers, since the older-younger relationship has not been reversed here-both the descendants of Sunjata, as well the descendants of Mande Bori, agree on it. ${ }^{40}$ Sunjata and Mande Bori were hunting companions. Once Mande Bori insulted Sunjata's sister, and for this reason he and his descendants can never be leader of the army (keletigi). In Kangaba this fact is seen as an explanation for Kangaba's superiority in relation to Hamana, but in Hamana this story is used to explain the alleged organizational chaos along the Niger. Thus, although the story has been mutually accepted, a reversal in the interpretation of the story has taken place.

A pattern, which may be predictable by now, can be seen in a Kangaba genealogy which accepts the Hamana claim of a third wife. Leynaud and Cissé give the following genealogy, which they claim to have recorded from griots at Kela:41

\section{The genealogy of the royal family as presented in Leynaud and} Cisse's Paysans Malinke (reduced version)

$\begin{array}{cccc}\text { Farako Makan } & \begin{array}{c}\text { Tasuma Berete } \\ \text { (first wife) }\end{array} & \begin{array}{c}\text { Nanandje } \\ \text { Camara } \\ \text { Kunkeny1 }\end{array} & \begin{array}{c}\text { Sogolon Kejugu } \\ \text { (third wife) }\end{array} \\ \begin{array}{c}\text { I } \\ \text { Mansa Dankaran }\end{array} & \begin{array}{c}\text { Mande Borl } \\ \text { Tuman }\end{array} & \begin{array}{c}\text { I } \\ \text { Sunjata }\end{array} \\ \text { I } & \text { I } & \text { I } \\ \text { Ketta-rulers } & \text { Keita-rulers } & \text { Keita-rulers } \\ \text { from Kis1 } & \text { from Hamana } & \text { from Kangaba }\end{array}$

As with the genealogy in figure 1, the descendants of Sunjata place themselves in the position of the youngest brother in relation to other rulers. The position of the younger brother is always worked out; Sunjata and Mande Bori are important heroes in the Sunjata epic. Apparently the younger brother position is prestigious at every level. Therefore the exception in Hamana is an important variation in the processes of reproduction in the genealogies. The position of the oldest brother represents a certain explanatory power, but is not common: the Keita in the Kisi region are not powerful, and this might explain why they were linked to the oldest brother Mansa Dankaran Tuman, a coward who fled from Sumaworo Kante and settled in the forests of Kisi. ${ }^{42}$ 
According to Person, the Keita from Joma represent imperial authority since, in almost all the genealogies, they are acknowledged as the oldest branch-i.e., oldest brother..$^{43} \mathrm{I}$ argue that this is a wrong judgment, mainly the product of a European idealized image of an empire. In order to make this argument plausible, I must explain what is represented by the position of the younger brother in genealogies.

Elsewhere I have discussed the image of the younger brother; here I will provide only a summary. ${ }^{44}$ Mande society has a patrilineal kinship system and a virilocal marriage system. The oldest son is the inheritor of the paternal compound and any adult man is supposed to stay in this place: his wife comes from another compound or another village. In daily life the position of a younger brother is closely related to the position of his older brother. If the paternal compound is not rich, the younger brother must leave, since his older brother has pre-emptive rights to succession. Both in traditions and in daily life the younger brother's fate is to engage in external activities such as trade or warfare. It is logical then to represent leadership in war by the image of a younger brother.

The older brother is surrounded by an idiom of immobility: he receives gifts, stays home, and symbolizes the reproduction of the compound. A representative story of this pattern explains why people of the same patronymic can belong to different status categories, a rather extraordinary condition according to the accepted ideology of the Mande social system. The Conde are noblemen in the Sankaran region in Guinea, although their client griots of the village of Fadama bear the same jamu Conde (=Kone). ${ }^{45}$

Les Condé de Fadama représentent la branche aînée du clan. Voici dans quelle circonstance celle-ci a été déclassée: les frères cadets partirent un jour en guerre et ramenèrent à Fadama un grand butin. Parmi les prisonniers se trouvait une belle femme que les vainqueurs avaient destinée au frère aîné. Celui-ci en fut ravi et épousa la prisonnière, elle lui fit un enfant, mais le jour du baptême de l'enfant, la femme révéla qu'elle était d'orıgine griote, ${ }^{46}$ du clan Kouyate. Ainsi donc, les héritiers du frère ne pouvaient plus prétendre au pouvoir. L'aîné accepta le fait accompli et Fadama, son village, devint le centre historique pour les pays du Haut-Niger.

Another well-known example of the division of labor between younger and older brothers is the story of the killing of the buffalo of Do, one of the most famous stories in Mande. This animal is killed by the youngest brother, the ancestor of the Traore noblemen. The oldest brother praises his youngest brother and thus becomes the ancestor of the Diabate griots, people who do not participate in warfare, but live by receiving gifts.

This is not to suggest that the younger brother is superior to the older, simply that brothers are different in relation to each other. Both positions can be prestigious, but there is a kind of task division between the older and the 
younger brother. This is illustrated by a story told by Bakari Sidiki Sumano, the president of the Union Nationale des Griots du Mali. First he told me the well-known siory of Mamadi Kanu. ${ }^{47}$ This king of Mande, an alleged ancestor of Sunjata, had three sons. The two oldest sons did not treat the people of Mande very well, so the Mande organized an ordeal to secure the succession of Mamadi Kanu's youngest son. Sunjata is considered to be a descendant of this youngest son of Mamadi Kanu.

In Bamako and the region of Kangaba, persons with the patronymic Sumano are considered to be descendants of the oldest son. It is interesting then how a Sumano concludes this story about his ancestor. Bakari Sidiki Sumano told it in the following way.

Mais puisque tous les trois frères, ils n'étaient pas dans la coup, le jeune, très emu, est venu devant son grand-frère pour le dire: "Voilà, grand-frère, ça c'est la choix de Dieu et des ancêtres. Sinon, je n'aurais jamais accepté de gouverner là òu toi tu...[not audible]. Mais c'est la choix de Dieu, c'est la choix de nos ancêtres. Nous ne pouvons que l'accepter. Voilà, pourquoi j'ai accepté la mission. Mais, c'est toi qui commanderas. Et moi, j'executerai. Si je prends un jour de...[not audible] pour aller combattre des gens, sans aucune autorisation, je prie Dieu pour que je n'arrive pas.

Mais, toi, tu restes. Toi, tu t'occuperas de la maison-même, tu t'occuperas de la famille. 'I na so mano'.

'I na so mano', en Malinke: tu tiendras la famille. Toi, tu t'occuperas de la famille. 'I na so mano'. Alors, notre nom vient de là: Sumano. ${ }^{48}$

Even more than the story about the Conde of Fadama, this recitation shows how prestigious the older brother can be represented. The balance has completely turned. Everyone who studies Mande oral tradition must be aware of this principle of changing balances. ${ }^{49}$ Status is often represented in kinship terms, in which one position in a lineage is the most prestigious only in a certain context and from a certain perspective.

The division of tasks between older and younger brothers is not restricted to oral tradition..$^{50}$ For instance, Samory Toure never led the armies during his battles with the French; this task was fulfilled by "younger brothers." He was involved in planning and making treaties, but he did so from a distance. Peroz mentioned another example: the chief of Kankan placed his younger brother in command of his army. ${ }^{51}$ Thus, the one who goes out in the field is always considered to be, and is represented as, a younger brother.

The position of the youngest brother means leadership in case of external threat; the younger brother leads the army both in times of communal attack and in communal defense. Therefore, the rulers of Kangaba were a very prestigious group, since they are represented as, and widely acknowledged to be, the youngest brother. 
On the other hand, within the area of power, a ruler has to confirm his position in terms of the older brother, since that position represents the continuity of power. Within its immediate area of influence, Kangaba claimed to be responsible for the reproduction of the paternal compound via a complicated argument. ${ }^{52}$ However, this story refers to a generation after "Kanda," and concerns some village in the immediate neighborhood of Kangaba.

Within the ruling family of Kangaba the rights of succession belong to the oldest person within the oldest branch. In this case succession goes along lines of collateral succession, in which age is the most important criterion. Therefore a Keita ruler needs to be represented in different positions in different contexts. How closer at home, how increasingly older he must represent himself, because his own kafu is the basis of his power. In this sense, this has been shown by history itself, since the "father" of the nineteenth-century rulers of Kangaba was an oldest son, and all his successors more or less legitimate, since they are said to have been educated at Segu. ${ }^{53}$

Kafuw did not conquer each other, but "war only altered the relations of power between such polities bringing about changes in their hierarchies of suzerainty." 54 In the relationships between kafuw, war and war leadership were the main points of discussion. Superiority in $k a f u$ relations was expressed in terms of the younger brother, who is called-in the case of Kangaba- "kanda" or "war chief." 55

It is plausible to think that leadership in times of war was the main point of discussion among ruling families. In his analysis of the warrior states of the middle Niger valley, Roberts writes that "the survival of each state depended on its capacity to make war." 56 I suppose that in Mande, the situation was comparable to its neighbors to the north. On the one hand, every ruling family had to have the capacity to make war against neighbors, but cooperation was necessary in times of a communal attack or defense. The leader in such a circumstance was the 'younger brother.'

If the war leader had represented himself as an older brother, the system would have collapsed. A war leader is expected to redistribute any booty gained during the fighting. In the case of Mande, the 'younger brother' gives to the 'older brother.' This is a natural process, because that is the way older and younger brothers should treat each other, in Mande and almost anywhere in Africa. However, if the war leader had been represented as an older brother, redistribution would be unnatural, and accumulation seemed normal. Such an accumulation would lead to destruction, since the war leader should not have the means to control his accumulated property. ${ }^{57}$ Therefore I would argue that Mande was a segmentary society, in which warfare was the reason and the idiom for cooperation.

The ruler of Kangaba was a mansa (commonly translated as "king"), and so were many other rulers. A mansa has hereditary rights, contrary to a keletigi, who is an ad hoc war leader. Moreover, there are faamaw. This word has never been well defined, although many authors give a definition which appears plausible. The faama seems to be something neither mansa nor 
keletigi. I think that Mande politics seem to have been based on the aim to be a mansa on a certain level and a keletigi on a higher level, that is 'the further from home.' This shift of titles, dependent on the level of organization and the partners for cooperation, may explain the Babel-like confusion on the translation of the terms mansa, faama, and keletigi. Scholars have always tried to define these terms in relation to the actual power or status of the person or family which was analyzed. I propose to see them as fluid terms which characterize certain aspects of a ruler in a specific contexts. Thus, at one moment, a person can be the mansa in relation to A, and a keletigi in relation to $\mathrm{B}$.

\section{V}

Person thought that the Sunjata epic was a kind of "section isolee, fossilisée." I will argue here that he was wrong to keep the Sunjata genealogies separate from his analysis-that the genealogies of the royal family show the principle of preference of the younger brother just as does the genealogy in figure 1.

However, one can remark, Sunjata is the middle brother most of the time, and almost never the youngest. I think that this represents a giant status claim by the rulers of Kangaba. The story of Mande Bori's insult clearly shows the position of Kangaba. The story secures both war leadership (keletigi) and hereditary kingship (mansaya) to the descendants of Sunjata in relation to the descendants of Mande Bori.

In another context, "closer to home"- that is, among the descendants of Sunjata - the ruler of Kangaba had the highest status, since he was accepted as the youngest brother and the most recent invader. Thus, taking into account these two levels, the rulers of Kangaba had the most prestigious position in relation to the descendants of Sunjata, as well as in relation to the descendants of Sunjata's brother.

This leads to a interesting picture of politics in a segmentary society. The rulers had to take account of the genealogy of figure 1. For instance, Nyagassola and Joma always disagree with Kangaba, unless the region is attacked from outside. Although the status of Kangaba, generally recognized as the youngest, had long been the case, this status has to be continually reconfirmed in power struggles, since all the older brothers (Figira or Nyagassola) try to subdue the youngest. Peace is always relative and relational. Being the younger brother shows high prestige, but does not mean absolute power. History has proven this, since the two older brothersNyagassola and Figira-were victorious in the end, albeit with the support of the French.

The fact that the Keita of Joma (who claim a relationship with Kita) are seen by Kangaba as the oldest brother of all shows the dynamics of regional politics: in relation to Kangaba, Joma has more freedom of action than Nyagassola. The actual obedience of Nyagassola to this order is shown by two historical events. The ruler of Nyagassola promised the Tukulor invaders to 
help them destroy Kangaba, but in the end guided their armies to another village which was burned down..$^{58}$ Moreover, as noted, he wanted Vallière to visit Kangaba, the seat of his "archenemy."

It is very plausible that powerful families worked together only in the case of an external threat. Peroz complained that regions joined each other only when attacked from outside; when the external threat disappeared, mutual hostility returns. ${ }^{59}$ This is virtually a model description of a segmentary society.

The return of old feelings of hostility is very logical, if one looks at the power of the keletigi. He threatens to suppress his companions, his 'older brothers,' if he stays too long in power. ${ }^{60}$ Take what happened to the chief of Kankan, who gave the function of "generalissime" to his younger brother, named Moriba. ${ }^{61}$ This Moriba suffered some defeats in the early $1860 \mathrm{~s}$ and decided to ask Nyagassola for military support. This temporary joint-venture led to a great deal of plundering, weakened the position of Kankan in the end, and brought booty to Nyagassola. This story makes clear that the keletigi enjoys enormous power in office. Therefore it is dangerous to continue collaboration between 'brothers' too long or to intensify collaboration too much, lest this lead to permanent subjection, and then to the title of faama on a 'higher' level.

Person's reading of oral traditions was based on patching up genealogies, but genealogies must be analyzed from generation to generation and as transformations of each other. The generation of Sunjata represents the widest scope; it encompasses all Mande. The level of the 'great-grandchildren' of Sunjata represents a discussion of only part of Mande, from Siguiri to Narena. Genealogies in which more recent descendants are involved actually represent status claims over even smaller areas.

Person's "exception" of Hamana (with Kouroussa as its center) actually shows a key principle in the genealogies, since the Kouroussa genealogy is a transformation of genealogies which are proclaimed elsewhere in Mande. Thus Kouroussa's independent course is in accordance with this exceptional genealogy.

My analysis suggests that many Mande genealogies are useless for the reconstruction of chronology. Genealogies often refer to divisions in terms of 'brotherly' tasks, and the succession of events is often no more than a claim to particular status. Contrary to what seems logical at face value, the status of a recent immigrant and the position of the youngest brother are very prestigious. This explains why Mande society is represented in stories as the product of a continuous flow of invasions. Actually, these mutually acknowledged immigrations show the stabilizing tendencies in society! Thus the French had no reason to expel the rulers of Kangaba on the basis on younger brotherhood or recent arrival, since both labels represented their most prestigious position in communal warfare in segmentary politics.

The fact that Kangaba was recognized as the 'youngest brother' by many other Mande rulers, the fact that it was the most powerful opponent of the French forces in Mande, and the fact that Kangaba had been a famous town for 
centuries, all suggest that Kangaba was something special. ${ }^{62}$ Therefore the hypothesis of Kangaba's recent rise lacks substantive evidence; it cannot be proved by oral data and there is no other evidence. There is still one argument, however, that makes sense: early Islamic sources do not mention Kangaba. Such absence of course cannot prove anything, since silence is so problematical as evidence.

\section{VI}

I have argued that Kouroussa's — and mainly Kangaba's - position in the genealogies accords with their prominent roles in Mande in precolonial times, if we analyze Mande as a segmentary society. Now I invite the reader to look at the written source that has always been used to prove that the Mali empire has disintegrated by the seventeenth century. The famous Tar'ikh as-Sudan tells us:

"La population de l'empire du Mali se divise en trois groupes. Chacun d'eux a à sa tête un pretendu sultan, mais les deux caïds méconnurent l'autorité de ces souverains et se déclarent également indépendants chacun de son domaine respectif." ${ }^{63}$

This is identical to the tripartition Sunjata-Mande Bori-Mansa Dankaran Tuman or, at another level, Kangaba/Figira/Nyagassola-Finadugu/Kanku Borithe two Jomas. It is also similar to Vallière's observation noted above that the "chefs appartiennent tous aux deux ou trois familles les plus illustres." It is interesting that Vallière could not decide whether there are two or three groups. This is exactly the Kangaba perspective versus the Kouroussa perspective. Kangaba claims that there are two groups, since Sunjata and Mande Bori are children of the same mother, whereas Kouroussa claims that there are three groups.

Actually, the Tar'ikh as-Sudan presents us a picture of a society in peace, since unity was necessary only in times of trouble or times of attack, when the youngest brother was in charge of conducting war. Another argument for such peaceful character is the fact that the "caids" do not recognize the authority of the "sultans." This is typical for a segmentary society. It would seem then that Mande/the Mali empire had not changed very much between ca. 1600 and 1880 , since the model that I presented in this paper seems to be the same as that offered by the Tar'ikh as-Sudan.

Moreover, the region called "Mande" had remarkable geographical stability. Mungo Park "arrived at Sibidooloo [=Siby-JJ], the frontier town of the kingdom of Manding." 64 The border of Mande was exactly north of Siby. After Park's horse had been stolen between Bamako and Siby by "Foulahs," the behavior of the friendly ruler of Siby suggests the existence of separated spheres of influence/territory: Siby's ruler had to send a delegation to Bamako in order to get the horse back, suggesting in turn that his sphere of influence stopped immediately north of Siby. 
A century later Vallière mentioned almost the same spot as the border of Mande, noting that Nafadié, where the village chief "est de la même famille que les Mambi de Nyagassola et Kangaba," was the border of Mande. ${ }^{65}$ Vallière also noted that the people of Siby "se bornent à ne pas s'allier officiellement avec les révoltes du Bélédougou et de Bammako."66 Thus, the same tension was still present, which leads me to believe that north of Siby ran a rather stable frontier of the Manding kingdom. In the twentieth century the same region is ruled by the descendants of the two middle brothers in figure $1 .{ }^{67}$

Did the Mali empire still exist in the nineteenth century? To a degree of course, the answer depends on the definition of "empire." 68 If an empire is defined as a centralized system of dominion or as a kingdom which has vassal kingdoms, then the Mali empire did not exist in the nineteenth century, since Mande then had a segmentary system with short-term collaboration between rulers. Moreover, Kangaba is said to have paid taxes to Segu, hardly suggesting a working empire. ${ }^{69}$

However, we do not know anything about the exact borders or organization of the society which is commonly accepted as "the medieval Mali empire," although Person has provided us with an elaborate analysis of the written sources. We know only that the medieval Mali empire had Sunjata as its 'founder,' it was located along the Niger, and that its king(s) were reputed to be rich. ${ }^{70}$

This absence of detailed information on the empire-as-it-really-was challenges me to hypothesize that the Mali empire still existed in the nineteenth century. It was located in Mande and it had a stable segmentary form of organization. If one looks to the system of tripartitions, 'genealogies of rulers' in the period from 1600 to 1880 , and border lines in the period from 1790 to 1880 , one sees a well-defined territory with a mutually acknowledged system of temporary alliances. Within this territory several groups or kings claimed a position of youngest in relation to others, but these claims are ordered along certain lines.

The borders of the nineteenth-century Mali empire may have been the strongholds at Kangaba and Kouroussa, towns with a renowned power in precolonial times. At its center was the Joma region. However, on the basis of the nature of the genealogies, Person's idea that the Joma rulers were the legitimate heirs of the imperial crown is not acceptable. Joma was just another powerful kafu in the struggle for war leadership among the kafuw of Mande.

Since kings claim war leadership as the keletigi over an area which is more extensive than they would control as a mansa, visitors to their courts can be misled by the image presented by the kings and their griots. This is an argument which must be taken into account in relation to the medieval Arab travel accounts, which ascribe great power and authority to the rulers of the Mali empire. If Arab travelers listened only to a very powerful king, they might well have got the wrong impression that Mali society was a centralized state. Different kings at different locations may have claimed to be 'the mansa of the Mali empire;' they may have considered their own 'hometown' as 'the 
capital of the Mali empire'. In effect, Arab travelers might have visited different alleged capitals of the Mali empire.

Moreover, Mande was able-on an ideological level-to endure domination by foreign powers, since these powers could be treated-with mutual agreement - as 'older brothers' who had to be respected and to whom gifts ought to be given. We know that Kangaba paid tribute to Segu, we know about the support which Mande kings gave to 'foreign' kings, but nothing is known about a permanent installation of 'foreign' armies in Kangaba. ${ }^{71}$ It seemed that the Mali empire could endure by virtue of the flexibility of its system, which is virtually impossible to suppress. ${ }^{72}$

Of course, it is possible that an extensive and well-organized empire called "Mali" collapsed and transformed itself into a segmentary system. The history of Africa does have examples of such a process. It is even possible that present-day Mande was never part of the medieval Mali empire, or only a peripheral part inhabited by acephalous groups. In that case the Sunjata ideology might have been adapted to a segmentary system which had never been brought under control by the center itself. After the center had fallen away, the periphery continued their successful adaptation of the royal ideology.

\section{VII}

In the present paper I reconsidered Person's analysis of oral tradition for post-imperial Mande. I have disagreed with his method of historical reconstruction, which consists of patching together a selection of genealogies, the so-called $k a f u$ traditions. I have argued that Person was wrong in not incorporating Sunjata traditions, and that he neglected to put genealogies into the mirror of other oral traditions.

Comparing Sunjata traditions, other oral traditions, and the kafu traditions, it is clear that the position of the youngest brother is that which is preferred. This position represents the status of war leadership in case of collaboration. That is why the Kela bards repeat again and again that Mansa Kanda is the youngest great-grandchild of Sunjata. On the other hand, this feature in the epic shows how much the story is the ideological model for the debate on war leadership. The Sunjata epic is not a "section fossilisée," but represents a contemporary debate in a patrilineal society with a virilocal marriage system.

Genealogies cannot be patched together because their functions vary. The genealogy of the royal family represents the status debate between regions dominated by Kangaba, Siguiri, and Kouroussa. It is an ideological model used in a debate, in which the youngest brother position or the middle brother position is favored, since it represents leadership in times of collaboration. The nature of this collaboration was always based on war, the task of the 'younger brother.' However, within itself, a ruling family will obey to rules of succession, in which the oldest candidates have the greater rights. The genealogies are products of the same debate, but for use in different contexts. 
Thus, on the one hand my reading of Mande oral traditions is an alternative to those who would use them as 'factual' evidence which can be used to reconstruct the past. On the other hand it is an attack to those who think that historical research cannot be done solely on the basis of oral tradition. I hope that I have clearly demonstrated that the very stable genealogies in Mande represent status relations among mansaw, and give a historical dimension to political and military processes in an extensive part of West Africa.

I challenge Person's point of view that there was no permanent structure between the $k a f u w .{ }^{73}$ There still is continuity within the royal genealogies and the kafuw genealogies, and the genealogies are transformations of each other, and this represents a "permanent structure." At one point in his article Person admitted that genealogies may represent relations among groups, but this is otherwise subordinated to his aim to reconstruct the genealogy of the legitimate heirs of the imperial title. ${ }^{74}$

This "permanent structure" can also be reconstructed from the area in which royal genealogies have been interacting with each other for a very long time. This leads to an image of a segmentary society along the western banks of the Niger, between some 20 miles south from Bamako and the forests of Kisi. Siguiri is at the geographical center of this region. The northern border was defended by the younger brother rulers of Kangaba, the southern border by the younger brother rulers from Kouroussa. These three groups recognized each other in their genealogies and attributed to each other prestigious positions (oldest brothers), but all represented themselves as the youngest brother. In the majority of the genealogical material, Joma has been attributed the oldest brother position, but this has nothing to do with legitimate rights of succession to the imperial throne, as Person thought. It is merely a logical consequence of Joma's central geographical position in the stable segmentary society called Mande.

The eastern and western borders of this society were formed by nature. To the east the Niger was a natural wall of defense; in times of emergency the Mande kings could withdraw to the eastern bank. ${ }^{75}$ The eastern bank of the Niger, however, was not a part of the society which enjoyed major status. The western border had been formed by the Mande hills, up to Kita, which is often mentioned as an older brother, as a location of origin, but never on the level of the royal family. Therefore its position in the segmentary society called Mande is relatively marginal to the trio of joma-Hamana-Kangaba.

It might be that I have misled readers with the provocative title of this paper, but I think that I have made at least a useful contribution to the history of West Africa by pointing out that precolonial Mande was better organized than has been thought: the history of Kangaba is not one full of coups d'état and usurping families. Mande appears to be a segmentary society in which genealogies represent a debate on ranking and cooperation. This cooperation had something to do with warfare, the means by which elites reproduced themselves. The stable character of the Mande as a segmentary society 
challenges the dominant view on the Malı empire as a more or less centralized system.

I might not have convinced readers that "the Mali empire" stıll existed in the nineteenth century, but I hope that I have offered some arguments to defend the idea that the Malı empire was a segmentary society, both earlier and in the nineteenth century, when it was much less extensive. I might conclude this paper with the statement that, given the importance attributed to the Sunjata epic, and given the stable character of this oral tradition, the Mali empire will strll exist in the twenty-first century.

\section{Notes}

1 Th1s paper presents some results of a research project financed by WOTRO, the Netherlands Foundation for the Advancement of Tropical Reseach, grant W 52533 I wish to thank Ralph Austen and Stephan Buhnen for their extensive comments durnng the writing of this paper David Conrad, John Hanson, and Herman van der Ploeg offered useful comments on an earler draft Thanks to Karın Vockung for producing the map

2 Yves Person, "Nyaanı Mansa Mamadu et la fin de l'empire du Mall" in Le Sol, la Parole et l'Ecrit Mélanges en hommage à Raymond Mauny (Parts 1981), 613-54, and D T Niane, Recherches sur l'Lmpire du Mall au Moyen Age (Paris 1975) Person collected his material in the period 1954 1958, and Niane must also have worked in the 1950s, since his arguments are a copy of his rather obscure articles in Etudes Guinéennes, n s 1-4(1959), 35-46, 1(1960), 17-36, 2(1961), 31-51

3 For instance, E Leynaud and $Y$ Cisse, Paysans Malinke du Haut Niger (Bamako, 1978), M Ly-Tall, L'empire du Malı (Dakar, 1977), Seydou Camara, "La tradition orale en question conservation et transmission des traditions historiques au Manden le centre de Kela et l'historre de Mininjan" (Thèse doctorat, Ecole des Hautes Etudes en Scrences Sociales, Pans 1990), and KL Green, "Mande Kaba,' the Capital of Malı a Recent Invention?" HA 18 (1991), 127-35

4 I will focus on this heurstic error Person also used the idea that "one name is equal to generation is equal to 30 years "I think that this idea is completely outdated nowadays, and that is why I do not see any reason to pay attention to it by repeating the arguments that others, in particular, David Henige, have already made

5 Person "Nyaani," 627

6 Ibid, 613,629

7 lbid, 629

8 Ibld

9 For the history of Kangaba see Leynaud/Cisse, Paysans Malınke, Camara, "Tradition oral," and Green, "Mande Kaaba"

10 Jan Jansen, De draalende put, een studie naar de relatte tussen het Sunjata epos en de samenleving in de Haut-Niger (Mali) (Leiden 1995)

11 "An Be Kelen/We Are One-Griot Music from Malı" (field recordings by Jan Jansen (PAN-records 2015CD, Leiden)

12 This is the reason why there is hardly any written material on this region

13 Vallère "Exploration du Lieutenant Vallère dans le Birgo et le Manding" in J S Gallen, Voyage au Soudan français (Haut Niger et pays de Segou) 1879-1881 (Paris, 1885), $256-58$

14 Ib1d, 338

15 Ibld, 578

16 J S Gallienı, Deux campagnes au Soudan françats, 1886-1888 (Parıs, 1891), 590

17 Leynaud/Cisse, Paysans Malinke, 47, although they do not mentron their source

18 Mungo Park, Travels into the Interior of Africa (London, 1983) Park wrote about Kangaba six times ibid, 147, 181, 197, 233, 243f , 248 (the index of the book mentions only three of these) 
19 ME Peroz, Au Soudan françats, souventrs de guerre et de musston (Pars, 1889), 252

20 Information on the ant1-Kangaba stance of French colomal administrators can be found in Leynaud/Cisse, Paysans Malinke, and Camara, "Tradition orale" Surprisingly, Green, "Mande Kaaba," does not use this information, and invents the notion of strong French support of Kangaba

21 Nyama or nyamana is equivalent to kafu, see Person, "Nyaanı," 24

22 Surprisingly, Leynaud/Cisse, Paysans Malınke, 144, say that they have not been able to 1 dentify the descendants of the Joma brothers However, for Person-who worked in Jomait is clear that the brothers represent the Joma region My main informant in Kela, Lansine Diabate, pointed south and sald "Guinea" when I asked about the two brothers

23 Leynaud/Cisse, Paysans Malinke, 145

24 Peroz, Au Soudan, 223

25 Stephan Buhnen, "In Quest of Susu," HA, 21(1994), 9

26 Vallı̀̀re, "Exploration," 314

27 This has been recorded by Camara, "Tradition orale," 133

28 Anonymous, Mintstere de la Martne et des Colontes-Sénegal et Ntger la France dans l'Afruque Occtdentale, 18791883 (Paris 1884)

29 Leynaud/C1sse, Paysans Mallnke, 271

30 For a discussion on the tension between half-brothers see CS Bird and MB Kendall, "The Mande 'Hero' in Explorations in African Systems of Thought (Bloomington, 1980), 13-26 For a critical comment on this article see J Jansen and C Zobel, "Beyond Bird and Kendall 1980" in The Younger Brother in Mande Ethnographic Studies on Legittmacy and Kinship Polttıcs, ed J Jansen and C Zobel, forthcomıng

31 D Cissé and M M Diabété, La dispersion des Mandeka (Bamako, 1970), $91-92$

32 Although Kita Kuru and Mansa Ganda are not mentioned as human beings (kings or brothers) in the pratse lines for Kita

33 Niane, Recherches, 96

34 Person, "Nyaan1," 631

35 Ibid, 647

36 Ibıd, 633-34

37 Ib1d, 631

38 For instance, it can be found in the three versions (recorded in 1923, 1979, and 1992) of the Sunjata epic told by the grots of Kela, the official court histonans of the rulers of Kangaba J Vıdal, "La légende officielle de Soundiata, fondateur de l'empire Manding," Bulletın du Comité d'Etudes Historiques et Sctentıfiques de l'Afrique Occtdentale Française, 7(1924), 317-28, M Ly-Tall, S Camara, and B Dioura, L'histoire du Mande d'après Jelt Kanku Madı Jabate de Kéla (Pans, 1987), J Jansen, E Duntjer, and B Tamboura, L'épopée de Sunjara, d'après Lansine Diabate de Kela (Le1den, 1995)

39 Niane, Recherches, $95 \mathrm{f}$

40 Information from David Conrad, August 1994 For the story see Ly-Tall, Histotre, 53f, and Jansen, Epopée, 133

41 Leynaud/Cisse Paysans Malinke Although I am surprised that this genealogy is sard to have Kela as its ongin, I do not consider it either to be wrong or pure concidence When I read through my fieldwork notes I found the following note made the day after my arrival in Mande (Kela, 25 October 1991, translated from the Dutch) "I explanned to D [male, son of L, crrca 20 years old] that I had come to hear stories about Sunjata He nodded and said "Yes, Sunjata and Mande Bor1" "Mande Bon, who 1s that" I asked D was astonished "You don't know him? He is the older brother of Sunjata"

42 Stephan Buhnen (personal communication, 2 May 1995) "I think that we may disregard the Kist Keita as actrvely engaged in the polntucal history of Manding, because of Kisi's out-of-the way locauon, its non-centralised political structure and 1ts Kisi (non-Mande) population Yet, in genealogies these marginal lineages may be used to play on the younger/older pattern"

43 Person, "Nyaan1," 627 
44 Jan Jansen, "The Younger Brother and the Stranger In Search of a Status Discourse for Mande," paper presented at the Third International Conference on Mande Studies, Leiden, March, 1995 See also the articles in Jansen/Zobel, Younger Brother

45 D T Niane "Historre et tradition histonque du Manding," Présence Africaine, 89 (1974), 65

46 She started to sing when the baby was born, according to M Conde, Etude d'une école de traditıon orale Fadama (Kouroussa) (Kankan, 1989), 9

47 For this story see the Kela versions of the Sunjata epic Ly-Tall, Historre, and Jansen, Épopée, 4552

48 Interview, 19 December 1992

49 Th1s is the key idea in Jansen De draatende put

50 A similar division exists between tasks attrubuted to the stranger (lolan in Bambara, "allochtone" in French) and the "founder" (duguren in Bambara, "autochtone" in French) This is partially a logical process If compounds split due to tension between brothers, the younger brother is bound to leave, since the oldest has the nght to succession When this younger brother has left he must necessarily arrive in another location In the perspective of the population of that location, he ts the stranger

This stranger and younger brother actually are two manifestations of the same social process and this comes to the fore in the tasks attributed to the stranger The function of village chief does not belong to descendants of the founder of the village, but to the family which is said to have settled "recently," A Mande village chtef is responsible for external contacts, for instance, he receives guests Thus both younger brother and stranger are responsible for the representation of 'the group' towards other groups Therefore, being the 'last arnved,' whether by birth or immigration is a very prestigious status position

The territory of the village is distributed by a so-called "earth chief," a descendant of the founder of the village Again, there is a simlarity The one who came first, comparable to the oldest brother, is the one responsible for the reproduction of the village or the compound For the analysis of the relations stranger founder see $\mathrm{J}$ L Amselle, Logiques méttsses, Anthropologie de l'tdenttte en Afrique et aulleurs (Par1s, 1990) and Jansen, Younger Brother

51 Peroz, Au Soudan, $385 f$

52 Jansen, Younger Brother, $14 \mathrm{f}$

53 Camara, Tradition orale, $124 \mathrm{f}$

54 Buhnen, "Quest," 3233

55 Ibid, 9

56 Richard L Roberts, Warriors, Merchants and Slaves The State and the Economy in the Middle Niger Valley, 1700-1914 (Stanford, 1987), 2 See also Jean Bazin, "Etat guerrier et guerres d'état" in Guerres de lignages et guerres d'états en Afrique, ed Jean Bazin and Emmanuel Terray (Par1s, 1982), 319-74

57 Roberts, Warnors

58 Peroz, Au Soudan, 239

59 Ibid, 38687

60 See, for instance, Roberts, Warrtors

61 Peroz, Au Soudan, 38586

62 Kangaba's prestige is such that it has become part of the history of foreign nation states At Guinea schools it is taught that Sunjata founded the Mali empire-pictured as a predecessor of the present day natıon state of Gumea-at the assembly at Kurukanfuga, a plain adjoming Kangaba This story in stıll widespread in Northeastern Gumea, in Hamana, where Mande Bori's descendants rule In the text editions of the Kela version it is not part of the Sunjata epic, although my informants knew the story very well

63 Camara, "Tradition orale," 113

64 Park, Travels, 187

65 Vallıère, "Exploration," 336

66 Ibıd, 330

67 Leynaud/Cisse, Paysans Malinke, 145, 448-51

68 Seydou Camara gave the following two arguments aganst my hypothesis, Bamako, 6 
October 1994 He was not convinced by my answers

69 For the relation between Kangaba and Segou see Roberts, Warriors, chapter 1, for oral traditions on this relationship see Camara, "Tradition orale," $124 \mathrm{ff}$

70 The territory of the Malı empire must have been greater than present Mande, that is, the triangle Kouroussa-Kita-Bamako, as demonstrated by both written and oral evidence The Mali empire stretched along the Niger up to Gao, mentioned as "Gaogao" in Arab sources AI 'Umarn wrote that Mali's capital was surrounded by the river Nile With such a description one is eager to search for its location in the Niger delta Since al-CUmari complaned about the unbearable heat in Malı, this can hardly refer to the present day Mande region, which has a very pleasant climate In this context it is interesting to note that even in the extremely wet year of 1994 the town of Kangaba, located five kllometers from the river Niger, was not surrounded by water, although the water almost reached the village at some spots

Interesting, and hitherto unmentioned, sociolinguistic information is given by Mungo Park On his way from Segou to Koulikoro, he noted (Travels, 177) "and I arrived in the evening at Taffara, a walled town, and soon discovered that the language of the natives was improved, from the corrupted dialect of Bambarra, to the pure Mandingo" This is interesting information in combination with the fact that the holy rocks in Koulikoro are considered to be a transformation of Sunjata's opponent Sumaoro Kante In the Kela version (Epopee, 160) of the Sunjata epic Sumaworo remarks that "this is the limit" at the moment he transforms himself into the rocks Sunjata replies that "you [Sumaworo] could never have stayed in Mande, if you had not done this "This means that Koulikoro is the limit of Sunjata's Mande, and this is strikingly similar to Park's observation of a lingustic border

Therefore the northern/northeastern border of the Mals empire/Mande seems to have 'crawled' in the upstream direction of the Niger from the Middle Ages onwards However, it is also possible that the Malı empire was 'chased' upstream, from the inner delta of the Niger to present-day Mande, since we never hear anything about the empire's borders in the southern direction

71 The only exception may be a "religious army" of Koranic teachers in Kangaba, since the Hardara are still an 1solated group in Mande society Ha1dara is a patronymic common in the north, but not in Mande The Haidara led the Koranic school at the former "royal" court in Kangaba (Vıdal, "Légende") In 1960 they all stıll lived together in Kela Leynaud/Cisse, Paysans malinke, 9, 136, mentroned for 1960900 Hardara in Haut-Niger, 770 of them living in Kela (ibid , 448) This may be the result of an immigration which 'really' happened However, there were sometımes foreign invaders in Kangaba see Roberts, Warriors, $44 \mathrm{f}$

72 This may explain why 'tradition' is still so vivid in present-day Mande, which is nowadays often accused of being a 'conservative' region

73 Person, "Nyaan," 627

74 Ibid, 637

75 Mambi, the ruler of Kangaba, had done so when the French armes attacked Kangaba 